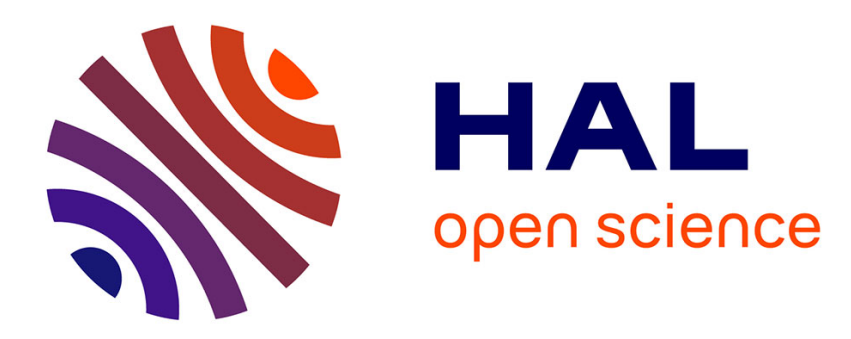

\title{
Stress Dependency on the Ultrasonic Wave Velocity and Attenuation of Fe-C System
}

\author{
S. Takahashi, K. Takahashi
}

\section{To cite this version:}

S. Takahashi, K. Takahashi. Stress Dependency on the Ultrasonic Wave Velocity and Attenuation of Fe-C System. Journal de Physique IV Proceedings, 1996, 06 (C8), pp.C8-845-C8-848. 10.1051/jp4:19968182 . jpa-00254619

\section{HAL Id: jpa-00254619 https://hal.science/jpa-00254619}

Submitted on 1 Jan 1996

HAL is a multi-disciplinary open access archive for the deposit and dissemination of scientific research documents, whether they are published or not. The documents may come from teaching and research institutions in France or abroad, or from public or private research centers.
L'archive ouverte pluridisciplinaire HAL, est destinée au dépôt et à la diffusion de documents scientifiques de niveau recherche, publiés ou non, émanant des établissements d'enseignement et de recherche français ou étrangers, des laboratoires publics ou privés. 


\title{
Stress Dependency on the Ultrasonic Wave Velocity and Attenuation of Fe-C System
}

\author{
S. Takahashi and K. Takahashi
}

Iwaki Meisei University, College of Science and Engineering, Chuoudai-lino, Iwaki-shi, Fukushima 970 , Japan

\begin{abstract}
The purpose of this study is to investigate stress dependency on ultrasonic wave propagating in stressed Fe-C systems containing 0.1 to 0.5 mass carbon. The Lamé constant, Poisson's ratio and Young's modulus were calculated from the data of the pulse echo method using $2 \mathrm{MHz}$ and $5 \mathrm{MHz}$ transducers for longitudinal and transverse waves. It was confirmed that the ultrasonic wave velocities changed with applied stress and this behavior can not be explained by the linear elastic theory.
\end{abstract}

\section{INTRODUCTION}

A fixed relation is recognized between stress and wave velocity by precise measuring the ultrasonic wave velocity propagating in the tensile stressed practical steels. Above experimental results were theoretically analyzed on the base of the Murnaghan's theory [1] [2]. In this report, stress-wave velocity and stress-attenuation relations were studied on the $\mathrm{Fe}-\mathrm{C}$ system samples containing little inpurity under compressive stress.

\section{EXPERIMENT}

\section{2,1 Tes $t$ s pec ime $n$}

Each of $0.1,0.3$, and 0.5 mass\%c was added to molten iron with 99. 99\% purity, melted and molded under the vacuum of $10^{-4}$ torr, hot pressed at about $1100^{\circ} \mathrm{C}$, annealed at $910^{\circ} \mathrm{C}$ for $3 \mathrm{hrs}$, air cooled out of the furnace, and then machined into cubes with a side $38 \mathrm{~mm}$ long for compression compress i ve 1 oad test. The specimen was set in the Instron type tensile testing machine as shown in Fig. 1. which gave compressive load by rising cross-head. The stress and strain were measured by the load cell and the strain gauge adhered on the specimen surface respectively.

The influence of interface friction between the loading rod and the specimen was reduced by specially designed jig using bearing balls. This jig was also necessary for setting the transducer on the specimen.

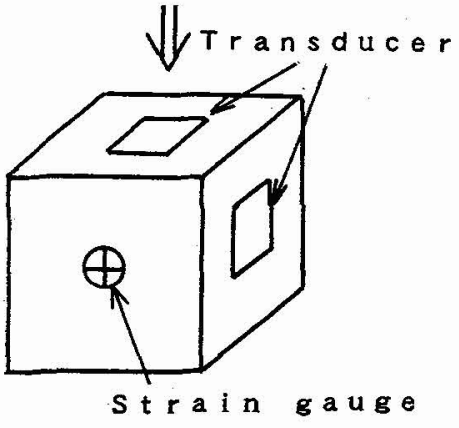

Figure 2 Sensor artangement.

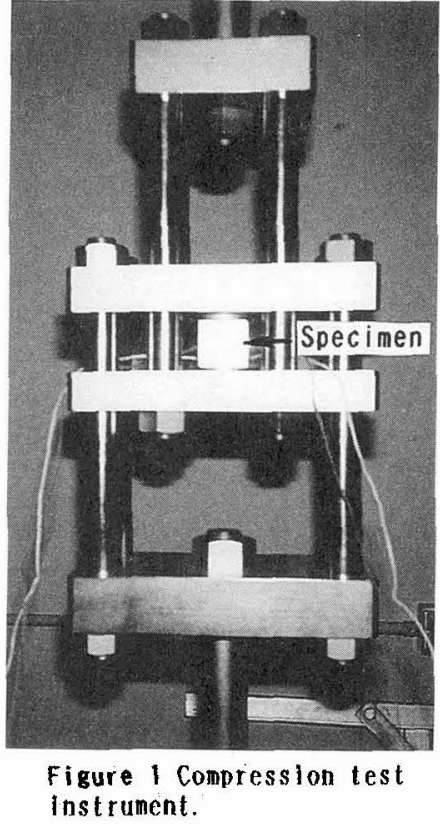




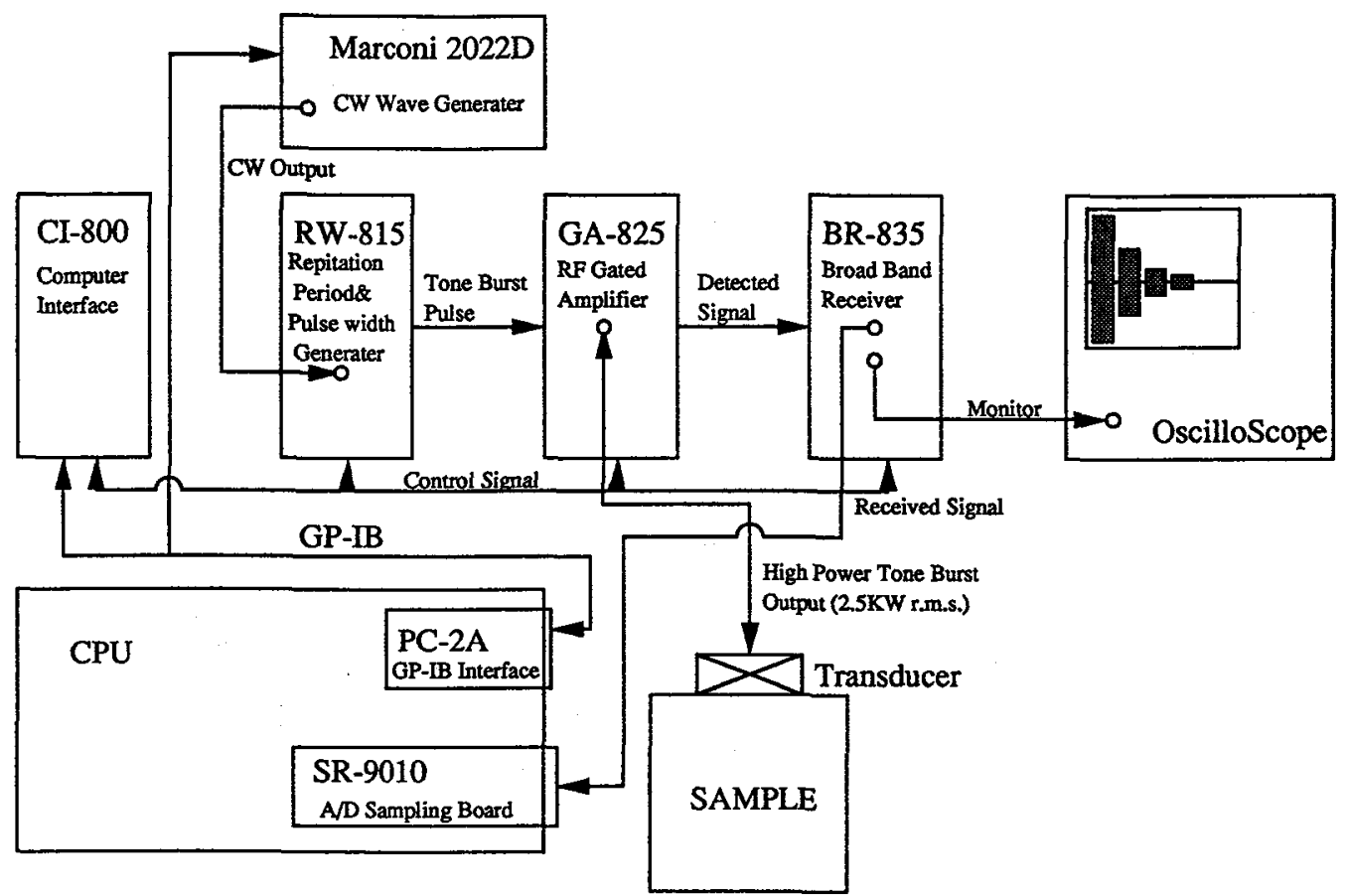

Figure 3 Block diagram of measurement instrument.

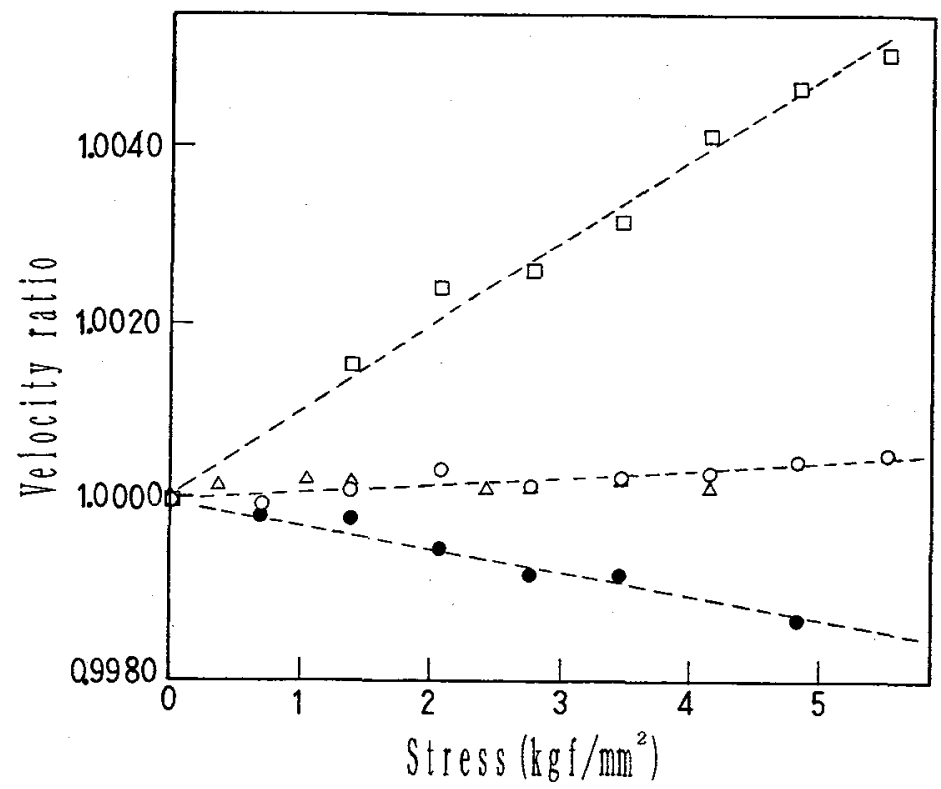

Figure 4 Relation between stress and changing ratio of ultrasonic wave velocity for Fe-0.5\%C O;transverse wave propagating along the direction perpendiculat to compression, $\Delta ;$ transverse wave propagating along the direction of compression,

- longitudinal wave propagating along the direction perpendicular to compression, $\square$; longitudinal wave propagating along the direction of compression. 


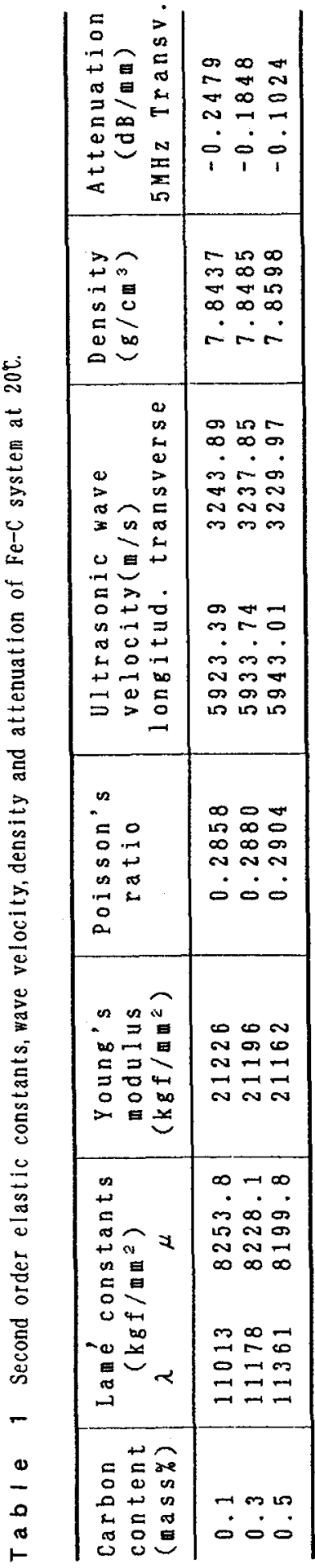

\section{2 Sensor a r r a n g ment}

Fig. 2 show the arrangement of the strain gauges and ultrasonic wave transducers used for this experiment.
2 .
Me a s u rement
a p parat u s

The Matec instruments MBS-8000 ultrasonic test system was used for the measurement of ultrasonic wave velocity and attenuation. Fig. 3 shows the schematic diagram of this system. An ultrasound pulse is introduced into one end of a sample. The first and the second echoes are received and the time of flight is obtained from these two measured echoes and digitized after mathematical correction.

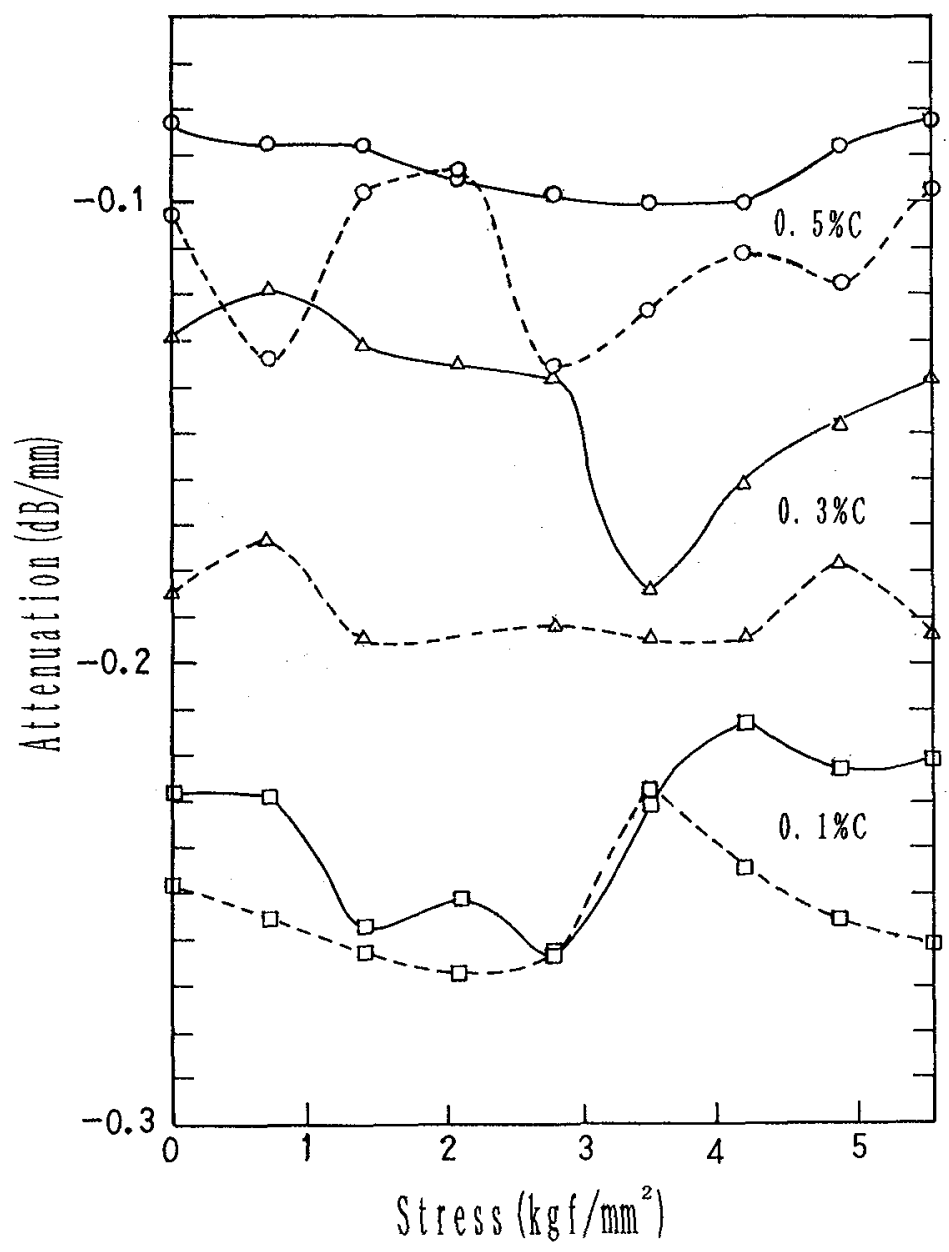

Figure 5 At tenuation-stress relations of $5 \mathrm{MHz}$ longitudinal (solid line) and transverse (dotted line) wave propagating along the $d i-$ rection perpendicular to compression for $\mathrm{F} e-\mathrm{C}$ systems. $\square ; F e-0.1 \% \mathrm{C}, \triangle ; \mathrm{Fe}-0.3 \% \mathrm{C}, \mathrm{O} ; \mathrm{Fe}-0.5 \% \mathrm{C}$. 


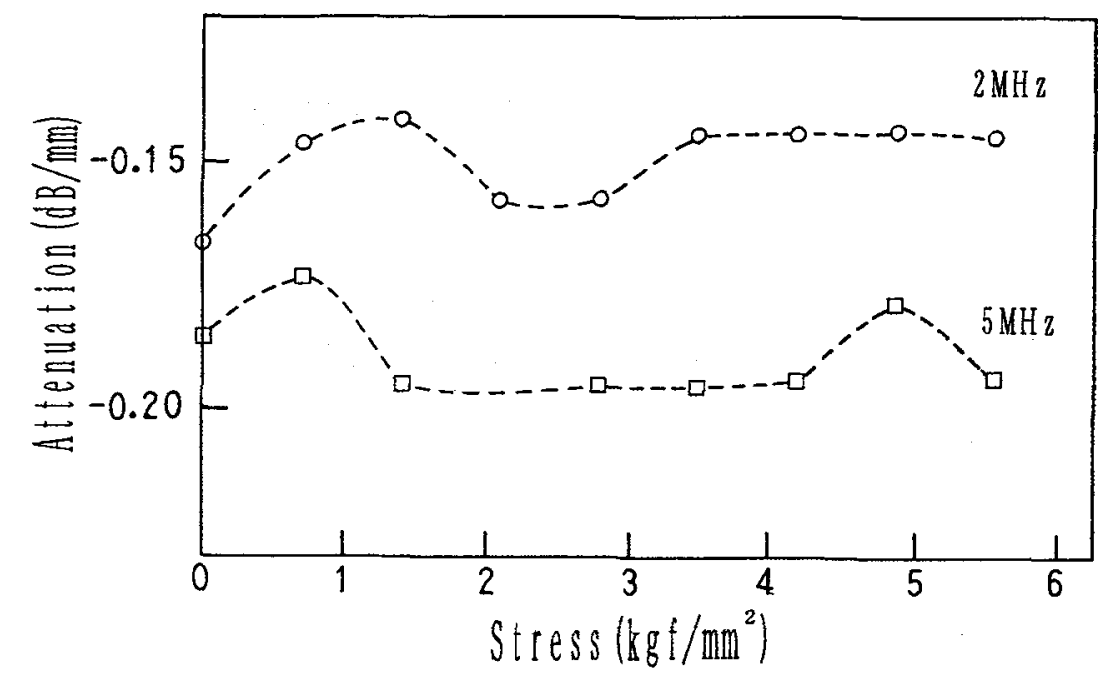

Figure 6 Attenuation-stress relations of $2 \mathrm{MHz}$ and $5 \mathrm{MHz}$ transverse wave for Fe-0. $3 \% \mathrm{C}$.

\section{RESULTS AND EXPLANATIONS}

Fig. 4 shows the changing ratio of the propagating velocity of the longitudinal and transverse waves along the compression axis and perpendicular to it for $\mathrm{Fe}-0.5 \% \mathrm{C}$. The ultrasonic wave velocity changed with the applied stress and the similar results were obtained for two other specimens. These behavior can not be dealt with the linear elastic theory. Fig. 5 shows the attenuation-stress relations of $\mathrm{Fe}-\mathrm{C}$ systems. The attenuation decreased with the increase of carbon content and that of longitudinal wave was smaller than that of transverse wave. It was also recognized that the attenuation changed with the applied stress. Fig. 6 shows the at tenuation change with stress for $\mathrm{Fe}-0.3 \% \mathrm{C}$ us ing $2 \mathrm{MHz}$ and $5 \mathrm{MHz}$ transducers.

Table 1 shows the second order elastic constants calculated from the measurement results and the attenuations of $5 \mathrm{MHz}$ transverse waves for each of stress free samples. From the Table, it is recognized that the values of $\lambda, \mu$, Young's modulus and Poisson's ratio are slight ly dependent on carbon content. The stress dependency of ultrasonic propagating velocity was found for each specimen, however the obtained nonlinear elastic constant were rather larger than expected. This is the subject for a future study.

\section{Acknow ledgments}

The authors mould like to thank T. Mitsui of National Research Institute for Metals and Showa Denko Co., Ltd. for preparing the samples.

References

[1] Takahashi S., Motegi R., J. Mater. Sci. 22 (1987) pp1850-1856.

[2] Murnaghan F. D. , Amer. J. Mathemat ics 49 (1937) pp235 